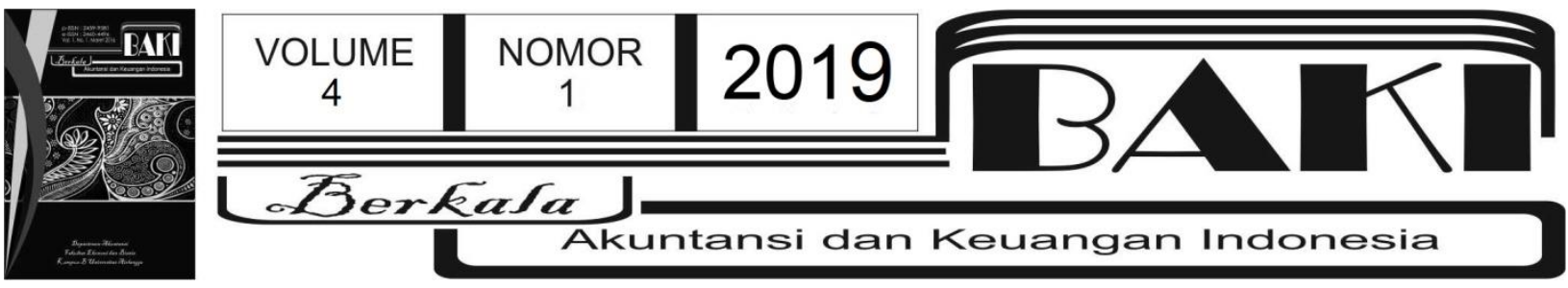

\title{
Pengaruh Agresivitas Pajak, Kinerja Laba dan Leverage Terhadap Transparansi Perusahaan
}

\author{
Fajar Rina Sejati ${ }^{1,2}$ \\ Septyana Prasetianingrum ${ }^{1,3}$ \\ ${ }^{1}$ Universitas Yapis Papua, Jayapura, Indonesia \\ 2avicennasejati@gmail.com \\ 3 prasetyaningrumseptyana@gmail.com
}

INFO ARTIKEL

Histori Artikel:

Tanggal Masuk 2 Juli 2019

Tanggal Diterima 23 Juli 2019

Tersedia Online 25 Juli 2019

Kata Kunci:

Agresivitas pajak; Leverage;

Kinerja Laba; Transparansi

Perusahaan

\begin{abstract}
A B STRAK
Penelitian ini bertujuan untuk menganalisis pengaruh agresivitas pajak (tax aggressiveness), kinerja laba, dan leverage terhadap transparansi perusahaan (corporate transparency). Metode penelitian menggunakan data sekunder yang keseluruhan data diambil pada laporan keuangan perusahaan yang terdaftar di BEI periode $2014-2017$. Metode analisis data yang digunakan dalam penelitian ini adalah analisis regresi linier bergdana. Dalam penelitian ini data akan diolah menggunakan software SPSS versi 25.0. Hasil penelitian ini menunjukkan bahwa Agresivitas pajak tidak berpengaruh terhadap transparansi perusahaan, Kinerja laba berpengaruh terhadap transparansi perusahaan, Leverage tidak berpengaruh terhadap transparansi perusahaan, Umur perusahaan berpengaruh terhadap tranparansi perusahaan, Ukuran perusahaan tidak berpengaruh terhadap transparansi perusahaan. Penelitian ini dilihat bahwa transparansi perusahaan itu merupakan suatu hal yang penting, diharapkan agar setiap perusahaan dalam menjalankan perusahaan secara etis menjaga transparansi perusahaan.
\end{abstract}

\section{Pendahuluan}

Perusahaan harus melakukan pengungkapan laporan keuangan yang lebih transparan dan lengkap guna mendukung pengambilan keputusan bisnis yang optimal agar dapat memenuhi kebutuhan informasi stakeholders atau calon investor.

Transparansi perusahaan diartikan sebagai ketersediaan informasi spesifik perusahaan kepada pemegang saham luar, mempengaruhi nilai perusahaan (Anggoro dan Septiani 2015). 
Setiap pemangku kepentingan yang ada di dalam perusahaan perlu mengetahui setiap informasi yang ada di dalam perusahaan agar dapat mengambil keputusan yang tepat untuk ke depannya. Transparansi mewajibkan adanya keterbukaan oleh perusahaan, tepat waktu, jelas dan dapat diperbandingkan.

Asimetri informasi sering terjadi antara manajer sebagai agen dan pemegang saham sebagai pemilik perusahaan dan pengguna laporan keuangan, sehingga dapat menyebabkan pemegang saham tidak dapat mengamati seluruh kinerja dan prospek perusahaan secara sempurna. Dengan adanya asimetri informasi ini, maka akan mendorong manajer untuk menyajikan informasi yang tidak sebenarnya, terutama jika informasi yang diberikan berkaitan dengan pengukuran kinerja manajer.

Di Indonesia, masalah transparansi perusahaan ini juga merupakan persoalan yang sangat diperhatikan. Koalisi Publish What You Pay (PWYP) Indonesia menemukan sedikitnya sepuluh perusahaan nonoperator dan 21 perusahaan mineral dan batu bara (minerba) tidak patuh dalam memenuhi Extractive Industries Transparency Initiative (EITI) periode 2012-2013 (Perkasa 2015). Deputi Bidang Koordinasi Pengelolaan Energi, Sumber Daya Alam, dan Lingkungan Hidup, Kemenko Bidang Perekonomian, Montty Girianna menyatakan bahwa dari ribuan perusahaan tambang di Indonesia, hanya beberapa yang berani membuka informasi kepada publik secara transparan (Situmorang 2019)

Transparansi perusahaan dikaitkan dengan upaya penghindaran pajak, juga terjadi di perusahaan multinasional di Indonesia yaitu perusahaan besar Google Indonesia. Google terbelit masalah pajak di Indonesia. Google dianggap mengemplang pajak karena belum menjadi Badan Usaha Tetap (BUT). Google Indonesia hanya beroperasi sebagai kantor perwakilan bukan sebagai Badan Usaha Tetap (BUT). Dengan demikian Google tidak pernah dipotong PPN maupun PPh-nya (Yusuf 2016). Beberapa kasus besar aggressive tax avoidance sudah dilakukan tindakan oleh Direktorat Jenderal Pajak (DJP), diantaranya kasus Asian Agri, Bumi Resources, Adaro, Indosat, Indofood, Kaltim Prima Coal (KPC) dan PT. Airfast Indonesia (anak perusahaan PT. Freeport Mc. Moran) (Rusydi 2018).

Dewasa ini telah banyak ditemukan perusahaan-perusahaan yang berupaya untuk melakukan agresivitas pajak. Meskipun pada kenyataannya tidak semua tindakan agresivitas pajak melanggar peraturan, namun dengan semakin banyaknya celah yang digunakan perusahaan untuk melakukan agresivitas pajak, maka perusahaan tersebut dianggap semakin agresif (Sari dan Martani 2010). Kasus yang terbaru dimana Lembaga Tax Justice Network telah melaporkan perusahaan tembakau milik British American Tobacco (BAT) yang melakukan penghindaran pajak di Indonesia melalui PT Bentoel Internasional Investama, dan mengakibatkan negara menderita kerugian US\$ 14 juta per tahun (Prima 2019).

Berdasarkan penelitian yang dilakukan oleh (Balakrishnan et al., 2012), faktor lain yang mempengaruhi transparansi perusahaan adalah kinerja laba. Penelitian tersebut 
mengungkapkan bahwa perusahaan yang mengalami keuntungan biasanya lebih transparan dibdaningkan dengan perusahaan yang mengalami kerugian.

Selain agresivitas pajak dan kinerja laba, leverage juga dianggap dapat mempengaruhi transparansi perusahaan (Balakrishnan et al., 2012). Leverage merupakan jumlah utang yang dimiliki perusahaan untuk pembiayaan dan dapat mengukur besarnya aktiva yang dibiayai utang (Yulfaida 2012). Perusahaan dengan leverage yang tinggi mengindikasi bahwa perusahaan tersebut bergantung pada pinjaman luar atau utang, sedangkan perusahaan dengan leverage rendah dapat membiayai asetnya dengan modal sendiri.

Berdasarkan latar belakang penelitian di atas, bahwa terdapat indikasi perusahaan dengan skala operasi yang besar kurang transparan dalam memberikan informasi perusahaannya ke publik. Dengan demikian, penelitian ini akan memberikan bukti empiris pengaruh agresivitas pajak, kinerja laba, dan tingkat hutang (leverage) dapat mempengaruhi tingkat transparansi perusahaan, sehingga merumuskan pertanyaan penelitiannya adalah sebagai berikut:

a. Apakah agresivitas pajak berpengaruh terhadap transparansi perusahaan?

b. Apakah kinerja laba berpengaruh terhadap transparansi perusahaan?

c. Apakah leverage berpengaruh terhadap transparansi perusahaan?

\section{Tinjauan Pustaka}

\subsection{Teori Keagenan}

Jensen dan Meckling (1976) mendefinisikan hubungan keagenan sebagai kontrak dimana satu atau lebih (principal) menyewa orang lain (agent) untuk melakukan suatu jasa sesuai dengan keinginan mereka dimana terdapat pendelegasian otoritas dalam pembuatan keputusan kepada agen.

Hubungan antara pemegang saham dan manajer perusahaan merupakan satu contoh yang memenuhi definisi hubungan keagenan yang murni, dimana pemegang saham sebagai principal akan menunjuk manajer sebagai agent untuk mengelola kekayaan yang dimiliki oleh pemegang saham. Pengelolaan yang dilakukan oleh manajer ini kemudian membutuhkan kontrol dan pengawasan dari pemegang saham sebagai pemilik kekayaaan (Jensen dan Meckling 1976).

\subsection{Teori Bid Ask Spread}

Mardiyah (2002) menyatakan bahwa bid-ask spread merupakan proksi yang salah satu komponennya berasal dari asimetri informasi (information assymetry). Biaya ini tercipta karena adanya dua pihak trader yang tidak sama dalam memiliki mengakses informasi. Informed trader 
sebagai pihak pertama memiliki informasi paling banyak sedangkan pihak lainnya yaitu uninformed trader tidak memiliki informasi. Ketidakseimbangan antara informed trader dan uninformed trader ini menyebabkan perilaku munculnya adverse selection dan moral hazard dalam perdagangan saham antar trader. Jika pihak informed trader melakukan transaksi dengan uninformed trader, maka uninformed trader dihadapkan pada resiko mengalai kerugian. Upaya dalam mengurangi resiko rugi ini tercermin di dalam bid-ask spread.

\subsection{Agresivitas Pajak}

Perusahaan terlibat dalam berbagai bentuk perencanaan pajak untuk mengurangi kewajiban pajaknya. Agar dapat memaksimalkan nilai perusahaan, terkadang pemilik atau pemegang saham menginginkan agar perusahaan bisa meminimalkan pembayaran pajaknya (Balakrishnan et al., 2012)

Pada penelitian ini, agresivitas pajak akan diukur dengan Effective Tax Rate (ETR). ETR bertujuan untuk melihat beban pajak yang dibayarkan dalam tahun berjalan, yang didalamnya mengdanung beban pajak kini dan beban pajak tangguhan. Penggunaan proksi ETR untuk mengukur agresivitas pajak diharapkan mampu memberikan gambaran menyeluruh mengenai perubahan beban pajak. Proksi ETR dinilai menjadi indikator adanya agresivitas pajak apabila memiliki ETR yang mendekati nol (Lanis dan Richardson 2012). Semakin rendah nilai ETR yang dimiliki perusahaan maka semakin tinggi tingkat agresivitas pajak. ETR yang rendah dapat menjadi indikator adanya tindakan agresivitas pajak (Balakrishnan et al., 2012).

\subsection{Kinerja Laba}

Perhitungan laba pada suatu perusahaan dilakukan setiap bulan, namun untuk tujuan praktis perhitungan laba dilakukan pada akhir periode akuntansi. Perhitungan inipun dimasukkan dalam suatu laporan laba rugi. Dan biasanya digunakan pimpinan perusahaan untuk mengevaluasi aktivitas operasi perusahaan dalam periode yang lalu, melakukan analisis dan memperbaiki untuk meningkatkan kemampuan unit usaha dalam menghasilkan laba.

Menurut Hendriksen dan Brede tujuan dari pelaporan laba perusahaan adalah untuk memberikan informasi yang berguna bagi orang-orang yang berkepentingan dalam laporan keuangan. Penelitian yang dilakukan oleh (Balakrishnan et al., 2012) mengatakan bahwa perusahaan yang mengalami keuntungan atau laba lebih transparan di dalam mengungkapkan mengenai informasi-informasi yang ada di dalam perusahaan termasuk informasi keuangan yang ada di dalamm suatu perusahaan.

\subsection{Leverage}


Leverage menggambarkan proporsi total utang perusahaan terhadap total aset yang dimiliki perusahaan dengan tujuan untuk mengetahui keputusan pendanaan yang dilakukan oleh perusahaan (Darmawan dan Sukartha 2014). Tinggi atau rendahnya risiko yang dihadapi oleh perusahaan menggambarkan tinggi rendahnya leverage perusahaan itu. Indikator leverage yang akan digunakan dalam penelitian ini adalah rasio total utang terhadap total aktiva (total liabilities to total asset). Rasio ini menekankan pada peran penting pendanaan utang bagi perusahaan dengan menunjukkan presentase aktiva perusahaan yang didukung oleh pendanaan utang.

\subsection{Tranparansi Perusahaan}

Transparansi perusahaan sebagai ketersediaan relevansi yang tersebar luas, informasi yang dapat dipercaya mengenai kinerja perusahaan dalam suatu periode yang terkait, posisi keuangan, kesempatan investasi, pemerintah, nilai dan risiko perusahaan dagang yang bersifat umum (Bushman dan Smith 2003). Selain itu, transparansi perusahaan diartikan sebagai keterbukaan informasi, baik dalam proses pengambilan keputusan maupun dalam mengungkapkan informasi material dan relevan mengenai perusahaan (Hapsari 2011). Menurut peraturan di pasar modal Indonesia, yang dimaksud dengan informasi material dan relevan adalah informasi yang dapat mempengaruhi naik turunnya harga saham perusahaan, atau yang mempengaruhi risiko serta prospek usaha perusahaan yang bersangkutan.

\subsection{Kerangka Konseptual}

\section{Gambar 1. Kerangka Konseptual}

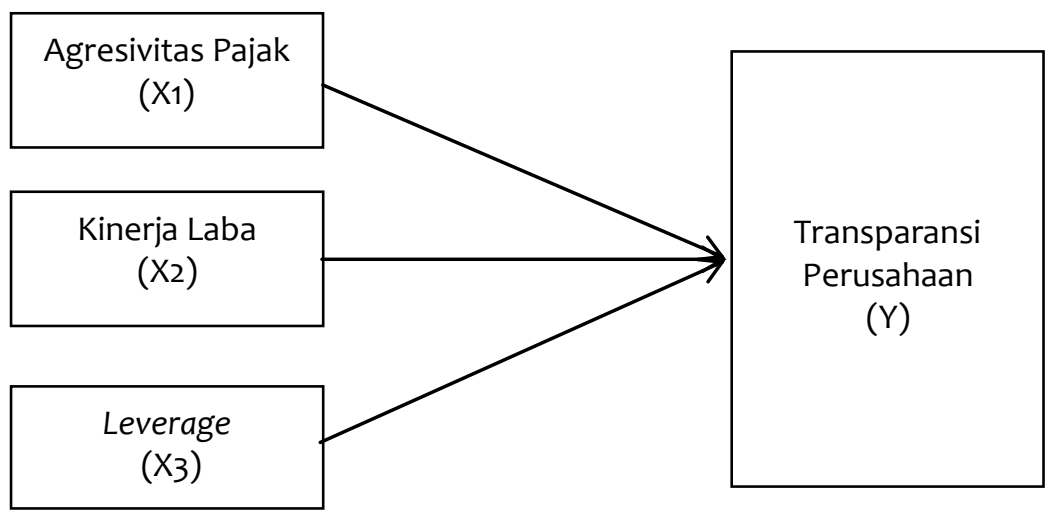




\subsection{Hipotesis Penelitian}

\subsubsection{Agresivitas Pajak dan Transparansi Perusahaan}

(Liando 2014) mengungkapkan bahwa jika biaya agensi mendominasi penghindaran pajak, maka akan memberi perlindungan kepada perilaku manajerial, dimana hal tersebut membawa keuntungan untuk manajer. Perusahaan yang tidak transparan akan mendukung hal ini, sehingga berdampak bagi pihak eksternal yaitu tidak memperoleh informasi yang transparan. Tindakan pajak agresif memberikan dampak yaitu investor akan mengalami kesulitan di dalam meramalkan laba absolut perusahaan, meningkatnya kesenjangan informasi antara investor yang sudah menerima informasi dengan investor yang belum menerima informasi, dan juga daat mendistorsi hubungan antara akrual dengan arus kas perusahaan (Balakrishnan et al., 2012). Berdasarkan uraian tersebut maka kesimpulan yang dapat diambil yaitu semakin tinggi agresivitas pajak perusahaan, maka semakin rendah transparansi perusahaan tersebut. Dengan demikian hipotesis yang dapat diajukan yaitu:

$\mathrm{H} 1$ : Agresivitas pajak berpengaruh negatif terhadap transparansi perusahaan

\subsubsection{Kinerja Laba dan Transparansi Perusahaan}

Penelitian yang dilakukan oleh (Balakrishnan et al., 2012) mengenai pengaruh agresivitas pajak terhadap transparansi perusahaan mengungkapkan bahwa salah satu faktor yang mempengaruhi transparansi perusahaan dalam mengungkapkan informasinya yaitu tingkat laba yang dimiliki yang dialami perusahaan tersebut. (Dichev dan Dechow 2001) mengatakan bahwa perusahaan yang mengalami kerugian biasanya tidak transparan dalam mengungkapkan informasinya dibdaningkan dengan perusahaan yang tidak mengalami kerugian. Berdasarkan uraian tersebut, maka hipotesis yang dapat diajukan yaitu:

H2: Kinerja laba berpengaruh positif terhadap transparansi perusahaan

\subsubsection{Leverage dan Transparansi Perusahaan}

Kebutuhan operasional dan investasi perusahaan harus tetap terpenuhi, untuk itu perusahaan dimungkinkan untuk menggunakan hutang dari kreditur. Hutang akan menimbulkan beban tetap bagi perusahaan yang disebut dengan bunga (Ariani 2017). Teori keagenan dapat digunakan untuk menjelaskan hubungan antara tingkat leverage perusahaan dengan pengungkapan informasi yang diberikan. Semakin tinggi tingkat leverage, maka perusahaan akan mengungkapkan lebih banyak informasi, karena biaya keagenan perusahaan dengan 
struktur modal seperti itu lebih tinggi (Jensen dan Meckling 1976). Berdasarkan uraian tersebut, maka hipotesis yang dapat diajukan yaitu:

H3: Leverage berpengaruh positif terhadap transparansi perusahaan.

\subsubsection{Umur Perusahaan dan Transparansi Perusahaan}

Penelitian ini juga menggunakan dua variabel kontrol yang dianggap telah robust hasilnya turut mempengaruhi transparansi perusahaan, yakni umur perusahaan dan ukuran perusahaan. Dalam penelitian yang dilakukan oleh Marwata (2001) menunjukan bahwa semakin lama berdirinya suatu perusahaan, maka perusahaan tersebut harus mengeluarkan lebih banyak biaya untuk mengungkapkan informasi tersebut, sehingga perusahaan akan melakukan upaya untuk menekan biaya-biaya yang harus dikeluarkan untuk mengungkapkan informasi tersebut. Sehingga cenderung perusahaan dengan umur yang sudah lebih tua terkadang tidak menunjukan transparansi perusahaan dengan baik.

\subsubsection{Ukuran Perusahaan dan Transparansi Perusahaan}

Ukuran perusahaan merupakan gambaran besar kecilnya suatu perusahaan. (Sudarmadji 2007) mengungkapkan bahwa semakin besar ukuran perusahaan maka semakin tinggi pula tuntutan terhadap keterbukaan informasi dibdaningkan dengan ukuran perusahaan yang lebih kecil. Dengan mengungkapkan informasi yang lebih banyak, maka akan mengurangi asimetri informasi yang terjadi dalam perusahaan. Berdasarkan uraian tersebut, maka hipotesis yang dapat diajukan yaitu:

\section{Metodologi Penelitian}

Dalam penelitian ini peneliti melakukan analisa menggunakan pendekatan kuantitatif dengan 4 variabel yang akan diukur yaitu Agresivitas Pajak $\left(X_{1}\right)$, Kinerja Laba $\left(X_{2}\right)$, Leverage $\left(X_{3}\right)$ sebagai variabel independen dan Transparansi Perusahaan $(Y)$ sebagai variabel dependen. Di samping itu, dalam penelitian ini juga terdapat 2 variabel kontrol yang masingmasing adalah umur perusahaan, dan ukuran perusahaan. Populasi yang digunakan dalam penelitian ini adalah perusahaan non keuangan sektor perdagangan jasa dan investasi yang terdaftar di Bursa Efek Indonesia (BEI) tahun 2013-2017.

Penelitian ini mengambil sampel perusahaan subsektor advertising, printing, media, jasa komputer dan perangkatnya. Untuk teknik pengambilan sampel menggunakan metode purposive sampling. Sumber data yang digunakan adalah data sekunder yang keseluruhan data diambil pada laporan keuangan perusahaan yang terdaftar di BEI periode $2014-2017$. 
Metode analisis data yang digunakan dalam penelitian ini adalah analisis regresi linier berganda. Dalam penelitian ini, data akan diolah menggunakan software SPSS versi 25.0.

\section{Analisis dan Pembahasan}

Penyelesaian masalah dalam penelitian ini menggunakan analisis regresi linier berganda.

Tabel 4.1. Hasil Uji Regresi Linier Bergdana

\begin{tabular}{lllll}
\hline Variabel & $\begin{array}{l}\text { Koefisien } \\
\text { Regresi } \\
\text { (B) }\end{array}$ & $\mathbf{T}$ & Sig & Ket. \\
\hline $\begin{array}{l}\text { Konstanta } \\
\text { Agresivitas }\end{array}$ & -1.695 & -1.482 & .151 & \\
$\begin{array}{l}\text { Pajak } \\
\text { Kinerja }\end{array}$ & 0.045 & .079 & .938 & $\begin{array}{l}\text { Tidak } \\
\text { signifikan }\end{array}$ \\
$\begin{array}{l}\text { Laba } \\
\text { Leverage }\end{array}$ & 0.122 & 2.143 & .042 & $\begin{array}{l}\text { Signifikan } \\
\text { Umur }\end{array}$ \\
$\begin{array}{l}\text { Perusahaan } \\
\text { Ukuran }\end{array}$ & 0.574 & 1.747 & .093 & $\begin{array}{l}\text { Tidak } \\
\text { signifikan }\end{array}$ \\
Perusahaan & -0.09 & -2.152 & .042 & Signifikan \\
\hline
\end{tabular}

Sumber : (Data diolah, 2018)

Persamaan regresi linier berganda dalam penelitian ini adalah sebagai berikut:

$\mathrm{Y}(\mathrm{TP})=-1.695+0.045($ Tax Agg) $+0,122($ Laba $)+0.574$ (LEV) - 0,09 (Age) - 0.041 (Size)

$+\mathrm{e} \quad(1)$

Berdasarkan hasil uji regresi berganda, maka variabel transparansi terjadi penurunan sebesar 1.695, apabila tidak ada variabel agresivitas pajak, kinerja laba, leverage, umur perusahaan dan ukuran perusahaan. Sementara, transparansi akan meningkat sebesar 0.045, apabila agresivitas pajak meningkat satu satuan. Transparansi akan meningkat sebesar 0.122 , apabila kinerja laba meningkat satu satuan. Transparansi akan meningkat sebesar 0.574 , apabila leverage meningkat satu satuan. Transparansi akan menurun sebesar 0.09, apabila umur perusahaan meningkat satu satuan, dan transparansi juga akan menurun sebesar 0.041 , apabila ukuran perusahaan meningkat satu satuan.

Untuk pengujian hipotesis, ditemukan hasil pengujian bahwa $\mathrm{H} 2$ dan $\mathrm{H} 4$ dapat diterima. Sementara, hasil pengujian untuk $\mathrm{H} 1, \mathrm{H} 3$, dan $\mathrm{H} 5$ ditolak. Hipotesis 2 yaitu kinerja laba berpengaruh positif terhadap transparansi perusahaan, dan hipotesis 4 yaitu umur perusahaan berpengaruh negatif terhadap terhadap transparansi perusahaan. Hasil penelitian ini menunjukkan bahwa agresivitas pajak, leverage, dan ukuran perusahaan tidak berpengaruh terhadap transparansi perusahaan, yang artinya bahwa perilaku perusahaan-perusahaan tersebut untuk semakin melakukan transparansi atau keterbukaan informasi tidak dipengaruhi 
oleh ada tidaknya tindakan agresivitas pajak yang dilakukan, tidak dipengaruhi oleh besar kecilnya hutang (leverage) dan besar kecilnya tingkat kekayaan perusahaan. Hasil ini sejalan dengan temuan (Liando, 2014).

Variabel kinerja laba berpengaruh positif dan signifikan terhadap variabel transparansi perusahaan, hal ini berarti bahwa perusahaan yang mengalami keuntungan atau laba, akan lebih transparan dalam mengungkapkan informasinya. Lain halnya dengan perusahaan yang memiliki kerugian atau tidak mengalami laba, maka perusahaan tersebut tidak transparan dalam mengungkapkan informasinya. Hasil ini sejalan dengan temuan (Balakrishnan et al., 2012) dan (Dichev dan Dechow 2001), dimana perusahaan yang mengalami kerugian biasanya tidak transparan dalam mengungkapkan informasi yang dimiliki. Semakin besar laba yang diperoleh perusahaan, maka perusahaan tersebut akan lebih terbuka dalam menyampaikan seluruh informasi keuangannya kepada para pemegang saham, agar dapat menarik pemegang saham untuk menanamkan sahamnya pada perusahaan tersebut.

Terkait variabel kontrol, umur perusahaan berpengaruh positif dan signifikan terhadap variabel perusahaan. Hal ini menyatakan bahwa semakin lama berdirinya suatu perusahaan, maka perusahaan tersebut harus mengeluarkan lebih banyak biaya untuk mengungkapkan informasi tersebut, sehingga perusahaan akan melakukan upaya untuk menekan biaya-biaya yang harus dikeluarkan untuk mengungkapkan informasi tersebut. Oleh karena itu, hasil penelitian ini sejalan dengan Marwata (2001) yang menyatakan bahwa perusahaan dengan umur yang sudah lebih lama terkadang tidak menunjukan transparansi perusahaan dengan baik.

Sesuai dengan teori keagenan, bahwa pemegang saham sebagai principal akan mendelegasikan pengelolaan perusahaan kepada manajer sebagai agent dengan tetap dilakukan pengawasan dari pemegang saham sebagai pemilik kekayaaan (Jensen dan Meckling 1976). Manajer sebagai pengelola perusahaan lebih banyak mengetahui informasi internal dan prospek perusahaan di masa yang akan datang dibandingkan pemegang saham. Oleh karena itu, sebagai pengelola, manajer berkewajiban memberikan sinyal mengenai kondisi perusahaan kepada pemilik. Sinyal yang diberikan dapat dilakukan melalui pengungkapan informasi akuntansi seperti transparansi laporan keuangan.

Pemegang saham cenderung menginginkan perusahaannya terus berjalan dalam jangka waktu yang lama dan mendapatkan laba yang setinggi-tingginya. Dengan demikian, manajer akan memaksimalkan pengelolaan manajemen sebaik mungkin dengan memberikan informasi mengenai kinerja perusahaan tersebut. Akan tetapi, informasi yang disampaikan terkadang diterima tidak sesuai dengan kondisi perusahaan sebenarnya. Kondisi ini dikenal sebagai informasi yang tidak simetris atau asimetri informasi. Asimetri informasi terjadi karena manajer lebih superior dalam menguasai informasi dibanding pemegang saham. Kondisi inilah yang berkaitan dengan teori bid ask spread, dimana pihak pertama lebih memiliki informasi 
paling banyak daripada pihak lainnya. Dengan demikian, ketidakseimbangan informasi antara kedua pihak tersebut akan semakin meningkat dengan kurangnya transparansi perusahaan. Dengan kata lain, transparansi perusahaan dan keterbukaan informasi perusahaan akan mengurangi tingkat asimetri informasi yang ada.

\section{Kesimpulan, Keterbatasan, dan Saran}

Hasil penelitian ini menunjukkan bahwa transparansi perusahaan tidak dipengaruhi oleh agresivitas pajak, leverage dan ukuran perusahaan. Kemudian, transparansi perusahaan dipengaruhi oleh kinerja laba dan umur perusahaan, karena perusahaan yang mengalami laba dalam prakteknya lebih transparan dibdaningkan dengan perusahaan yang mengalami kerugian. Sementara itu, semakin lama berdirinya suatu perusahaan, maka perusahaan tersebut harus mengeluarkan lebih banyak biaya untuk mengungkapkan informasi. Dengan demikian, perusahaan akan melakukan upaya untuk menekan biaya-biaya yang harus dikeluarkan untuk mengungkapkan informasi tersebut. Perusahaan dengan umur yang sudah lebih lama terkadang cenderung tidak menunjukkan transparansi perusahaan dengan baik.

\section{Daftar Pustaka}

Anggoro, Stevanus Tri, dan Aditya Septiani. 2015. Analisis Pengaruh Perilaku Penghindaran Pajak Terhadap Nilai Perusahaan Dengan Transparansi Sebagai Variabel Moderating. Diponegoro Journal of Accounting 4 (4): 1.

Ariani, Anita. 2017. Optimalisasi Manajemen Piutang Pada UD. Mitrasantika Furniture Di $\begin{array}{llllll}\text { Surabaya. } & \text { Skripsi } & S 1 & \text { Universitas } & \text { Narotama Surabaya. }\end{array}$ http://karyailmiah.narotama.ac.id/files/OPTIMALISASI\%20MANAJEMEN\%20PIUTANG\%2 OPADA\%20.pdf

Balakrishnan, Karthik, Jennifer L. Blouin, dan Wayne R. Guay. 2012. Does Tax Aggressiveness Reduce Financial Reporting Transparency? SSRN Electronic Journal, no. 215. https://doi.org/10.2139/ssrn.1792783.

Bushman, Robert M. dan Smith, Abbie J.. 2003. Economic Policy Review / April 2003 65 Transparency, Financial Accounting Information, dan Corporate Governance. Economic Policy Reveiw, no. April: 65-87.

Darmawan, I. G. H., dan I. M. Sukartha. 2014. Pengaruh Penerapan Corporate Governance, Leverage, Return on Assets, Dan Ukuran Perusahaan Pada Penghindaran Pajak. Jurnal Akuntansi 9 (1): 143-61.

Dichev, I., dan P. Dechow. 2001. The Quality of Accruals dan Earnings: The Role of Accrual $\begin{array}{lllll}\text { Estimation } & \text { Errors. } & \text { Accounting } & \text { (2002): }\end{array}$ 
http://papers.ssrn.com/sol3/papers.cfm?abstract_id=277231.

Hapsari, Indri. 2011. Hubungan Antara Good Corporate Governance Dan Transparansi Dengan

Kinerja Perusahaan. Skripsi S1 Universitas Diponegoro Semarang. http://eprints.undip.ac.id/27390/1/JURNAL.pdf

Jensen, Michael C. dan W.H. Meckling. 1976. Theory of The Firm: Managerial Behavior, Agency Cost dan Ownership Structure. Journal of Financial Economics 3. hal 305-360.

Lanis, Roman, dan Grant Richardson. 2012. Corporate Social Responsibility dan Tax Aggressiveness: An Empirical Analysis. Journal of Accounting dan Public Policy 31 (1): 86-108. https://doi.org/10.1016/j.jaccpubpol.2011.10.006.

Liando, Mariska Marcelina. 2014. Pengaruh Agresivitas Pajak Terhadap Transparansi Perusahaan. Skripsi S1 Universitas Katolik Widya Mandala Surabaya. http://repository.wima.ac.id/3741/

Mardiyah, Aida Ainul. 2002. Pengaruh Informasi Asimetri Dan Disclosure Terhadap Cost of Capital. Jurnal Riset Akuntansi Indonesia 5 (2): 229-56.

Marwata. 2001. Hubungan Antara Karakteristik Perusahaan dan Kualitas Ungkapan Sukarela dalam Laporan Tahunan Perusahaan Publik di Indonesia. Simposium Nasional Akuntansi IV. Hal 155-173.

Perkasa, Anugerah. 2015. PWYP: 31 Perusahaan Ekstraktif Tak Transparan. https://ekonomi.bisnis.com/read/20151130/44/496910/pwyp-31-perusahaan-ekstraktif-taktransparan.

Prima, Benedicta. 2019. Tax Justice laporkan Bentoel lakukan penghindaran pajak, Indonesia rugi US\$ 14 juta. https://nasional.kontan.co.id/news/tax-justice-laporkan-bentoel-lakukanpenghindaran-pajak-indonesia-rugi-rp-14-juta.

Rusydi, M Khoiru. 2018. Pengaruh Ukuran Perusahaan Terhadap Aggressive Tax Avoidance Di Indonesia. Jurnal Akuntansi Multiparadigma. DOI: http://dx.doi.org/10.18202/jamal.2013.08.7200

Sari, Dewi Kartika, dan Dwi Martani. 2010. Ownership Characteristics, Corporate Governance, dan Tax Aggressiveness. Accounting Conference, 27-28.

Situmorang, Anggun P. 2019. Pemerintah Minta Perusahaan Tambang Lebih Transparan. https://www.liputan6.com/bisnis/read/3916700/pemerintah-minta-perusahaan-tambanglebihtransparan?related=dable\&utm_expid=.9Z4i5ypGQeGiS7w9arwTvQ.1\&utm_referrer=https \%3A\%2F\%2Fwww.liputan6.com\%2Ftag\%2Fperusahaan-tambang.

Sudarmadji, Ardi Murdoko. 2007. On the Dynamic Range of Coefficients Generated in Transform Processing of Digitised Image Data. IEE Proceedings F Communications, Radar dan Signal Processing 132 (2): 107. https://doi.org/10.1049/ip-f-1.1985.0021.

Yulfaida, Dewi. 2012. Pengaruh Size, Profitabilitas, Profile, Leverage Dan Ukuran Dewan 
Komisaris Terhadap Perusahaan Manufaktur. Diponegoro Journal of Accounting 1 (1): 111.

Yusuf, Oik. 2016. Masalah Pajak yang Membelit Google di Indonesia. https:/tekno.kompas.com/read/2016/09/19/09153207/masalah.pajak.yang.membelit.googl e.di.indonesia?page=all 